\title{
Estimating relative cellulolytic and ligninolytic enzyme activities as functions of lignin and cellulose content in decomposing plant litter
}

\author{
Michaela G. Margida ${ }^{\mathrm{a}}$, Gwenaëlle Lashermes ${ }^{\mathrm{b}}$, Daryl L. Moorhead, ${ }^{\mathrm{a},{ }^{*}}$ \\ aDept. of Environmental Sciences, University of Toledo, 2801 W. Bancroft St., Toledo, OH 43606-3390, USA \\ ${ }^{b}$ FARE Laboratory, INRA, Université de Reims Champagne-Ardenne, 51100, Reims, France
}

\section{Highlights}

- Lignocellulose index (LCI) controls microbial allocation of extracellular enzymes

- We provide an analytical solution to the LCI control on enzyme allocation

- The ratio of cellulose-to-lignin degrading enzyme activities declines with increasing LCI

- LCI threshold values at which ligninolytic enzymes are allocated varies among studies

\begin{tabular}{l} 
Keywords \\
\hline Decomposition \\
Extracellular enzyme \\
Lignin \\
Lignocellulose Index \\
Carbon use efficiency
\end{tabular}

\section{Introduction}

Various aspects of plant litter quality affect decomposition rates (Berg and Staaf 1980, Melillo et al. 1989, Bengtsson et al. 2018). An important one is the carbon quality of litter determined by the relative proportions of different chemical compounds, such as cellulose, hemicellulose and lignin. These are the main constituents of the plant cell wall and the most abundant forms of organic matter in terrestrial ecosystems (Klemm et al. 2005). However, cellulose and hemicellulose are energy rich polysaccharides whereas lignin is a polyphenolic compound and likely energy sink for catalysis (Kirk and Farrell 1987). For these reasons, the microbial carbon use efficiency (CUE; herein assumed to be the fraction of decomposed substrate carbon fixed into microbial biomass) of holocellulose is

\footnotetext{
${ }^{*}$ Corresponding author

e-mail addresses: michaela.margida@rockets.utoledo.edu (Michaela G. Margida), gwenaelle.lashermes@inrae.fr (Gwenaëlle Lashermes ), daryl.moorhead@utoledo.edu (Daryl L. Moorhead)
} 
Post-print published in revue Soil Biology and Biochemistry, Volume 141, February 2020, 107689

generally considered to be positive, whereas the CUE for lignin may be negative if the energetic cost of lignin decay is greater than the yield despite the possible assimilation of some lignin carbon into microbial biomass. The two compounds usually decompose at different rates and many decomposition models have long separated them into different pools (Paul and Juma 1981). In brief, microbes preferentially attack the high-energy holocellulose litter fractions during decomposition, yielding monosaccharides like glucose and xylose that are readily metabolized by microorganisms and thereby increasing the lignin concentration of remaining litter (Melillo et al. 1989). However, biochemical linkages between polysaccharides and lignin may also necessitate the breakdown of lignin to increase access to holocellulose (Sinsabaugh and Follstad Shah 2011, Talbot and Treseder 2012, Campbell et al. 2016).

Hydrolytic enzymes such as betaglucosidases (BG) depolymerize cellulose, which has a linear chemical structure offering sequential binding sites for enzymes. In contrast, oxidative enzymes (OX) such as phenol oxidases and peroxidases depolymerize lignin, which has an irregular structure composed of several types of linkages and subunits that limits effective binding sites for enzymes. Lignin present in plant litter affects decomposition rates by reducing holocellulose accessibility to enzymatic hydrolysis both physically (Boerjan et al. 2003) and chemically by non-specific enzyme binding (Hammel 1997). Consequently, the lignocellulose index (LCI = lignin/[lignin + hollocellulose]) of plant litter has long been a strong predictor of decomposition rate (Meentemeyer 1978, Whittinghill et al. 2012) and likely influences the microbial allocation of extracellular enzymes that catalyze the degradation of lignocellulose.

To our knowledge, the effects of LCI on the relative activities of cellulolytic and ligninolytic enzymes have not been explicitly examined. In contrast, Moorhead et al. (2013) described the control of LCI on empirical, first order decay rate coefficients $\left(\mathrm{k}_{\mathrm{i}}\right)$ for hollocellulose $\left(\mathrm{C}_{2}=\right.$ cellulose + hemicellulose $)$ and lignin $\left(\mathrm{C}_{3}\right)$ between LCI values ranging from 0 (plant litter contains no lignin) to 0.7 (the empirical maximum amount of lignin, defined by Melillo et al. 1982), by assuming an energetic cost-benefit relationship between $\mathrm{C}_{2}$ and $\mathrm{C}_{3}$ decomposition. Carbon use efficiency for $\mathrm{C}_{2}$ was considered to be positive, whereas CUE for $\mathrm{C}_{3}$ was negative; as LCI increased, realized CUE for lignocellulose decay decreased. Although a negative CUE seems counterintuitive, it simply represents the net cost rather than gain in energy from the degradation of lignin (Moorhead et al. 2013), a cost that is met by the net yield of energy from the degradation of holocellulose. In this model, the decay rate coefficient for holocellulose, $\mathrm{k}_{2}$, is a piecewise, declining linear function of LCI, changing slope at an LCI value ( $\mathrm{LCI}_{\mathrm{THR}}$ ), at which lignin begins to decay and above which the decay rate coefficient for lignin, $\mathrm{k}_{3}$, is an increasing linear function of LCI. Because hydrolytic enzyme activity catalyzes holocellulose decomposition, and oxidative enzyme activity drives lignin decomposition, LCI should relate to the proportion of hydrolytic and oxidative enzyme activity (Sinsabaugh 2010) needed to estimate the decay rate coefficients $\left(\mathrm{k}_{\mathrm{i}}\right)$ for holocellulose and lignin, respectively.

To our knowledge, previous decomposition models have not included LCI as a control on enzyme expression. However, several recent models of plant litter decomposition incorporated enzyme pools using either the reverse Michaelis-Menten (RMM) or standard Michaelis-Menten (MM) equations (Tang 2015). The simplest have one substrate pool that is degraded by one enzyme (e.g., Schimel and Weintraub 2003), while the most complex include multiple enzyme pools that degrade multiple substrate pools (Allison 
Post-print published in revue Soil Biology and Biochemistry, Volume 141, February 2020, 107689

https://doi.org/10.1016/j.soilbio.2019.107689

M.G. Margida et al. (2020)

2005, Moorhead et al. 2012, Abramoff et al. 2017). In contrast, a suite of recent soil carbon partitioning studies (Cotrufo et al. 2015, Soong et al. 2015, Campbell et al. 2016) examined the relationship between LCI and soil organic carbon formation, but without explicitly incorporating extracellular enzyme activities. An intermediate example is the Millennial model (Abramoff et al. 2018), which used microbial biomass as a proxy for enzymes in MM formulations.

In summary, the mechanisms of plant litter decomposition are complicated by the physical and chemical links between holocellulose and lignin that require different enzymes to cleave. However, existing enzyme-based models have not addressed interactions between these substrate pools. Our goal was to develop a model to calculate the allocation of hydrolytic and oxidative enzymes to match observed decay rates of holocellulose and lignin, respectively, given litter LCI (Moorhead et al. 2013).

\section{Modeling methods}

\subsection{Rationale}

Our model balances holocellulose $\left(\mathrm{C}_{2}\right)$ hydrolysis by cellulolytic enzymes $\left(\mathrm{E}_{2}\right)$ with lignin $\left(\mathrm{C}_{3}\right)$ degradation by oxidative enzymes (E3). A key assumption of this model is that enzyme-catalyzed reactions tend to occur at roughly half the theoretical maximum rate (kMAX) (Sinsabaugh et al. 2014); thus V MAX $2 \cdot \mathrm{kMAX} \cdot \mathrm{C}$ for use in the RMM equation. The justification for this assumption is that enzymes rarely face selection pressures that would require them to operate at maximum efficiency and so moderately efficient enzymes actually optimize resource gain from multiple reactions (Bar-Even et al. 2011, Kari et al. 2019). Moreover, the half-saturation coefficients in these equations $\left(\mathrm{K}_{\mathrm{M}}\right)$ that approximate substrate concentrations optimize the responsiveness of reaction rates (Klipp and
Heinrich 1994). Thus, the relationship between $\mathrm{V}_{\mathrm{MAX}}$ and $\mathrm{K}_{\mathrm{M}}$ should be tightly constrained, as verified in a recent metaanalysis by Sinsabaugh et al. (2014). Given the above assumption, the decay of $\mathrm{C}_{2}$ and $\mathrm{C}_{3}$ can be estimated with the RMM equation as $\mathrm{dC}_{\mathrm{i}} / \mathrm{dt}$ $=\left(2 \cdot\left(\mathrm{kMAXi}_{\mathrm{i}} \cdot \mathrm{C}_{\mathrm{i}}\right) \cdot \mathrm{E}_{\mathrm{i}}\right) /\left(\mathrm{K}_{\mathrm{Ei}}+\mathrm{E}_{\mathrm{i}}\right)$, where $\mathrm{K}_{\mathrm{Ei}}$ is the half saturation constant for enzyme concentration $\left(\mathrm{E}_{\mathrm{i}}\right)$ and $\mathrm{kMAXi}_{\mathrm{i}}$ is the maximum decay rate coefficient for first-order estimates of decomposition rates of substrates (Moorhead et al. 2013). In the present study, realized $\mathrm{k}_{\mathrm{i}}$ varies with LCI so that the allocation of enzymes should also change with LCI. All model parameters are listed in Table 1.

The allocation of enzyme pools was determined by setting RMM functions equal to decay rates estimated by first-order equations for both holocellulose and lignin. The linear functions of $\mathrm{k}_{\mathrm{i}}$ at given LCI described by Moorhead et al. (2013) were used in place of the decay rate coefficients in these equations. When $\mathrm{LCI} \geq \mathrm{LCI}_{\mathrm{THR}}$ :

$$
\begin{aligned}
& \left(2 \cdot\left(\mathrm{kMAX}_{\mathrm{MA}} \cdot \mathrm{C}_{2}\right) \cdot \mathrm{E}_{2}\right) /\left(\mathrm{K}_{\mathrm{E} 2}+\mathrm{E}_{2}\right)= \\
& \left(\mathrm{m}_{3} \cdot \mathrm{CUE}_{2} / \mathrm{CUE}_{3} \cdot\left(\mathrm{LCI}-\mathrm{LCIMAX}_{2}\right)+\right. \\
& \left.\mathrm{k}_{\mathrm{MAX} 3}\right) \cdot \mathrm{C}_{2} \\
& \left(2 \cdot\left(\mathrm{kMAX}_{3} \cdot \mathrm{C}_{3}\right) \cdot \mathrm{E}_{3}\right) /\left(\mathrm{K}_{\mathrm{E} 3}+\mathrm{E}_{3}\right)= \\
& \left(\mathrm{m}_{3} \cdot \mathrm{LCI}+\mathrm{k}_{\mathrm{MAX}}\right) \cdot \mathrm{C}_{3}
\end{aligned}
$$

and when $\mathrm{LCI}<\mathrm{LCI}_{\mathrm{THR}}$ :

$$
\begin{aligned}
& \left(2 \cdot\left(\mathrm{kMAX}_{2} \cdot \mathrm{C}_{2}\right) \cdot \mathrm{E}_{2}\right) /\left(\mathrm{K}_{\mathrm{E} 2}+\mathrm{E}_{2}\right)= \\
& \left(\mathrm{m}_{2} \cdot \mathrm{LCI}+\mathrm{k}_{\mathrm{MAX} 2}\right) \cdot \mathrm{C}_{2} \\
& \mathrm{dC}_{3} / \mathrm{dt}=0
\end{aligned}
$$

where $\mathrm{m}_{\mathrm{i}}$ are the slopes of $\mathrm{k}_{\mathrm{i}}$ versus LCI (Moorhead et al. 2013). These equations were 
Post-print published in revue Soil Biology and Biochemistry, Volume 141, February 2020, 107689

then solved for $\mathrm{E}_{2}$ and $\mathrm{E}_{3}$ in terms of $\mathrm{kMAXi}_{\mathrm{M}}$ $\mathrm{K}_{\mathrm{Ei}}, \mathrm{LCI}, \mathrm{LCI}_{\mathrm{MAX}}$, and $\mathrm{CUE}_{\mathrm{i}}$, when $\mathrm{LCI} \geq$ LCITHR:

$$
\begin{aligned}
& \mathrm{E}_{2}=-\mathrm{K}_{\mathrm{E} 2} \cdot\left(\mathrm{CUE}_{2} \cdot \mathrm{LCI} \cdot \mathrm{m}_{3}-\mathrm{CUE}_{2} \cdot\right. \\
& \left.\mathrm{LCIMAX} \cdot \mathrm{m}_{3}+\mathrm{CUE}_{3} \cdot \mathrm{kMAX}_{3}\right) /\left(\mathrm{CUE}_{2}\right. \\
& \cdot \mathrm{LCI}_{2} \cdot \mathrm{m}_{3}-\mathrm{CUE}_{2} \cdot \mathrm{LCIMAX}_{3} \cdot \mathrm{m}_{3}-2 \cdot \\
& \left.\mathrm{CUE}_{3} \cdot \mathrm{kMAX}_{2}+\mathrm{CUE}_{3} \cdot \mathrm{kMAX}_{3}\right) ; \\
& \mathrm{E}_{3}=-\mathrm{K}_{\mathrm{E}} \cdot\left(\mathrm{LCI} \cdot \mathrm{m}_{3}+\mathrm{kMAX}_{3}\right) /(\mathrm{LCI} \\
& \left.\cdot \mathrm{m}_{3}-\mathrm{k}_{\mathrm{MAX}}\right)
\end{aligned}
$$

Using the parameter estimates of Schimel and Weintraub (2003) and Moorhead et al. (2013), and assuming that $\mathrm{K}_{\mathrm{E} 2}=\mathrm{K}_{\mathrm{E} 3}$ (Table 1), the only variable in equations $1-8$ is LCI, assuming that $\mathrm{CUE}_{2}$ and $\mathrm{CUE}_{3}$ are constant. Although the values of $\mathrm{K}_{\mathrm{E}}$ are unlikely to be identical, we found that modest variations did not substantially alter the patterns of model behavior. Thus, the relative allocations of $\mathrm{E}_{2}$ and $\mathrm{E}_{3}$ may be estimated by LCI of litter residue to meet empirical patterns of lignocellulose decomposition.

\subsection{Validation}

Relatively few decomposition studies report both LCI and extracellular enzyme activity (EEA) over sufficient time to show substantial changes in LCI and make it possible to define LCITHR value. For example, Lashermes et al. (2016) conducted a 126-day

\begin{tabular}{|c|c|c|c|}
\hline Parameter & Value & & Units \\
\hline $\mathrm{k}_{\mathrm{MAX} 2}$ & 0.1 & $\begin{array}{l}\text { Maximum } \\
\text { substrate decay } \\
\text { rate coefficient for } \\
\text { cellulose }\end{array}$ & $\mathrm{d}^{-1}$ \\
\hline $\mathrm{m}_{2}$ & -0.170 & $\begin{array}{l}\text { Slope of substrate } \\
\text { decay rate } \\
\text { coefficient for } \\
\text { cellulose }\end{array}$ & $d^{-1}$ \\
\hline $\mathrm{CUE}_{2}$ & 0.5 & $\begin{array}{l}\text { Microbial carbon } \\
\text { use efficiency of } \\
\text { cellulose }\end{array}$ & unitless \\
\hline $\mathrm{k}_{\mathrm{MAX} 3}$ & 0.01 & $\begin{array}{l}\text { Maximum } \\
\text { substrate decay } \\
\text { rate coefficient for } \\
\text { lignin }\end{array}$ & $d^{-1}$ \\
\hline $\mathrm{m}_{3}$ & 0.033 & $\begin{array}{l}\text { Slope of substrate } \\
\text { decay rate } \\
\text { coefficient for } \\
\text { lignin }\end{array}$ & $d^{-1}$ \\
\hline $\mathrm{CUE}_{3}$ & -0.21 & $\begin{array}{l}\text { Microbial carbon } \\
\text { use efficiency of } \\
\text { lignin }\end{array}$ & unitless \\
\hline $\mathrm{LCI}_{\mathrm{THR}}$ & 0.4 & $\begin{array}{l}\text { Threshold at which } \\
\text { lignin decay begins }\end{array}$ & unitless \\
\hline $\mathrm{LCI}_{\mathrm{MAX}}$ & 0.7 & Maximum LCI & unitless \\
\hline $\mathrm{K}_{\mathrm{E} 2}$ & 0.3 & $\begin{array}{l}\text { Enzyme half } \\
\text { saturation constant } \\
\text { for cellulose }\end{array}$ & $\mathrm{mg} \mathrm{C} / \mathrm{g}$ \\
\hline $\mathrm{K}_{\mathrm{E} 3}$ & 0.3 & $\begin{array}{l}\text { Enzyme half } \\
\text { saturation constant } \\
\text { for lignin }\end{array}$ & $\mathrm{mg} \mathrm{C} / \mathrm{g}$ \\
\hline
\end{tabular}
laboratory study of lignocellulose decay in maize (Zea mays L.) leaves, steams, and roots

\section{Table 1}

Parameters used in the modelling cellulolytic and ligninolytic enzyme allocations.

inoculated with a basidiomycete (Phanerochaete chrysosporium). They reported a final mean LCI value of about 0.22 and a mean $\mathrm{BG} /(\mathrm{BG}+\mathrm{OX})$ value of 0.99 ; thus, LCI was too low to initiate much oxidative enzyme activity. In contrast, Snajdr et al. (2011) measured mass loss, holocellulose and lignin content, and extracellular enzyme activity during oak (Quercus petraea) litter decomposition in a forest over two years near Prague, Czech Republic. Litter lignin content was relatively high at $38 \%$ of initial mass, and LCI values increased to approximately 0.69 by the end of the study. Although LCI was not reported on all dates of enzyme measurements, LCI was linearly related to remaining litter 
Post-print published in revue Soil Biology and Biochemistry, Volume 141, February 2020, 107689

$\operatorname{mass}\left(\mathrm{LCI}=0.0021 \cdot \operatorname{Mass}+0.5690, \mathrm{~N}=5, \mathrm{R}^{2}\right.$ $=0.8733)$ and we used this relationship to estimate LCI for observed values of mass loss concurrent with all observations of enzyme activities. We selected the activity of BG as an index to holocellulose decay and the combined activities of peroxidase and phenol oxidase $(\mathrm{OX})$ as an index to lignin decay. The observed relationships between $\mathrm{BG} /(\mathrm{BG}+\mathrm{OX})$ and $\mathrm{LCI}$ in decaying litter were compared to our model results.

We also constructed a second validation exercise by combining the datasets from studies by Magill and Aber (1998) and Carreiro et al. (2000). Magill and Aber (1998) conducted field decomposition studies of oak (Quercus velutina) and maple (Acer rubrum) litter over 2 years at Harvard Forest, Mass., in which they measured mass loss, lignin, and cellulose content. Although Magill and Aber (1998) did not measure EEA, final LCI values ranged 0.55-0.65. In comparison, Carreiro et al. (2000) measured mass loss and EEA during long term decomposition of oak (Quercus rubra) and maple (Acer rubrum) litter near New York, NY, but did not continuously measure lignin or cellulose content. We combined the datasets from these field studies to extrapolate relationships between EEA and LCI given mass loss patterns of similar litter types under similar field conditions. In the study by Magill and Aber (1998), LCI was linearly related to percent mass loss in decomposing oak litter $(\mathrm{LCI}=0.0018 \cdot$ Mass $\left.+0.4554, \mathrm{~N}=13, \mathrm{R}^{2}=0.7503\right)$ and maple litter $\left(\mathrm{LCI}=0.0010 \cdot\right.$ Mass $+0.5368, \mathrm{~N}=12, \mathrm{R}^{2}=$ $0.5226)$. These relationships were used to estimate LCI at observed values of mass loss for both oak and maple litter, concurrent with observations of enzyme activities (Carreiro et al. 2000). Again, we selected the activity of BG as an index to holocellulose decay and the combined activities of peroxidase and phenol oxidase (OX) as an index to lignin decay and compared relationships between observed $\mathrm{BG} /(\mathrm{BG}+\mathrm{OX})$ and $\mathrm{LCI}$ in decaying litter to our model estimates as a second validation exercise.

\section{Results}

Our model allocated holocellulose and lignin degrading enzymes in response to residue LCI as functions of carbon use efficiency similar to the pattern of first-order decay rate coefficients (Fig. 1). The cellulose decay rate coefficient $\left(\mathrm{k}_{2}\right)$ decreased linearly by $70 \%$ as LCI increased from 0 to 0.4 (LCI THR), and by another $67 \%$ as LCI increased from 0.4 to 0.7 , whereas the lignin decay rate coefficient $\left(\mathrm{k}_{3}\right)$ increased linearly from 0 to $0.01 \mathrm{~d}^{-1}$ as LCI increased from 0.4 to 0.7 (Fig. 1a). The simulated patterns of activities for cellulolytic $\left(\mathrm{E}_{2}\right)$ and ligninolytic (E3) enzymes approximated these patterns for decay rate coefficients; the allocation of $\mathrm{E}_{2}$ decreased by $76 \%$ as LCI increased from 0 to 0.4 , and by another $74 \%$ as LCI increased from 0.4 to 0.7 (Fig. 1b). In contrast, $\mathrm{E}_{3}$ increased from 0 to $0.3 \mathrm{mg} \mathrm{C} \mathrm{g}^{-1}$ soil as LCI increased from 0.4 to 0.7 (Fig. 2). Despite differences in the relative magnitudes of changes in $\mathrm{k}_{\mathrm{i}}$ 's and $E_{i}$ 's with changing LCI, simulated enzyme activities during decay generally followed the patterns of change in empirical decay rate coefficients.

The relationships between EEA and LCI (Fig. 2) support the notion that tradeoffs in realized CUE balance lignin and holocellulose decay (Moorhead et al. 2013). In brief, as LCI increases during decomposition, the increased density of biochemical linkages between holocellulose and lignin necessitate the increased degradation of lignin to access holocellulose. The degradation of lignin is an energy-expensive process, defined herein as having a negative CUE (a net energy cost, as per Moorhead et al. 2013), resulting in a realized CUE for lignocellulose decomposition that declines as LCI increases. 
Post-print published in revue Soil Biology and Biochemistry, Volume 141, February 2020, 107689

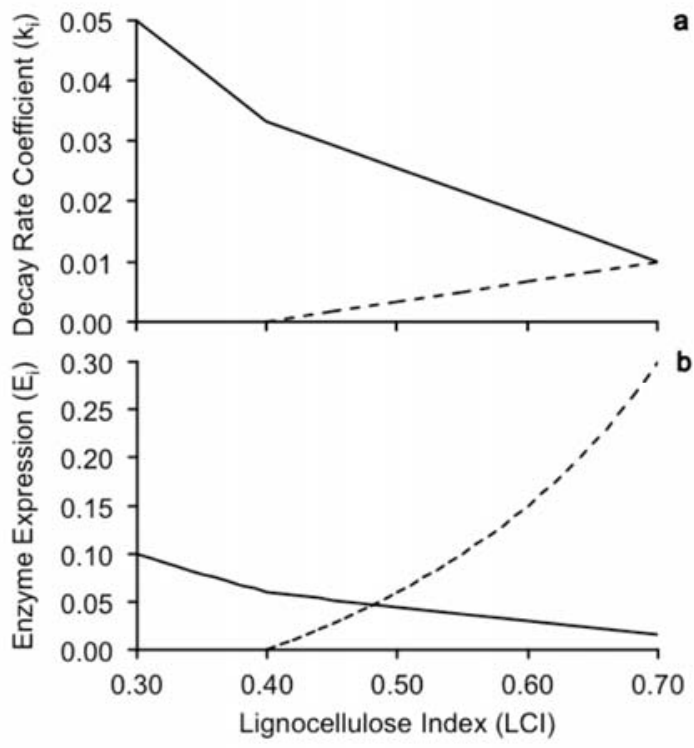

Fig. 1. a. Decay rate coefficients $\left(\mathrm{d}^{-1}\right)$ for holocellulose (solid line) and lignin (dashed line) and b. amounts (mg $\mathrm{C} \mathrm{g}^{-1}$ soil) of apparent cellulolytic (solid line) and ligninolytic (dashed line) enzyme activities vs. litter LCI.

In all cases, the relationship between $\mathrm{BG} /(\mathrm{BG}+\mathrm{OX})$ and $\mathrm{LCI}$ was negative above a threshold value of LCI (LCITHR), consistent with observations by Herman et al. (2008), although the LCI threshold for oxidative enzyme activity in experimental studies differed from the expected value of LCITHR $_{T}=$ 0.4. In the northeast USA, studies by Magill and Aber (1998) and Carreiro et al. (2000) suggested a LCI threshold for oxidative activity of about 0.45 for oak (Fig. 2b) and 0.55 for maple litters (Fig. 2c). In contrast, the Snajdr et al. (2011) data suggest a LCI value of about 0.60 for oak litter decomposing in the Czech Republic (Fig. 2a).

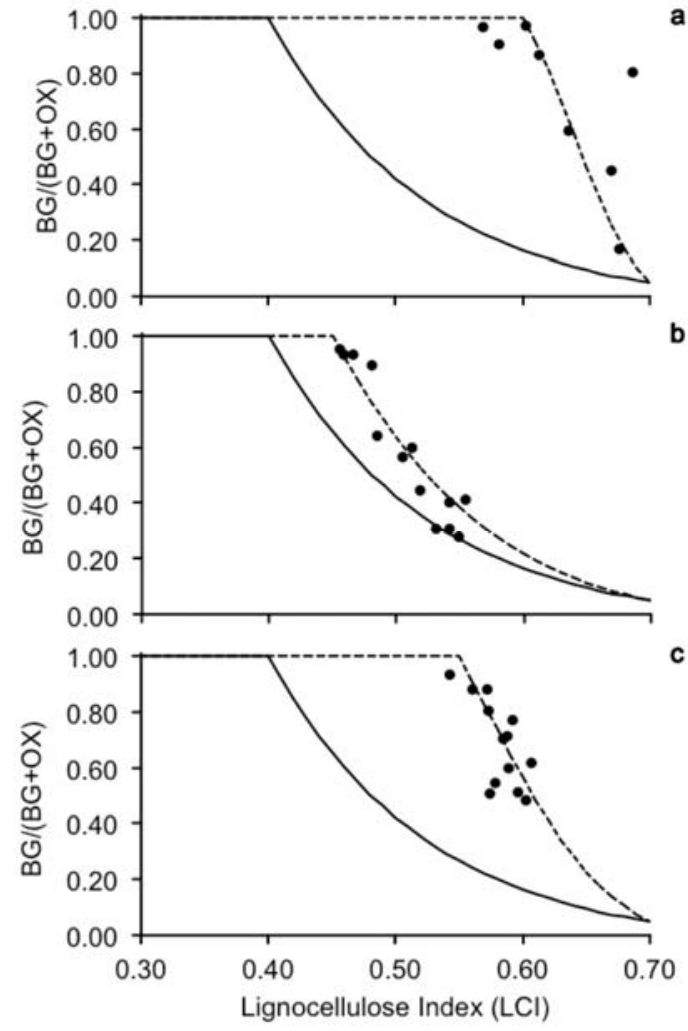

Fig. 2. Relationships between the allocation of apparent enzyme activities $(\mathrm{BG} /[\mathrm{BG}+\mathrm{OX}])$ and litter LCI during decomposition. Simulations with an LCI threshold $=0.4$ are in solid lines and alternative model thresholds suggested by observations are shown by dashed lines: a. estimated oak litter LCI from Snajdr et al. (2011) including an alternative model LCI threshold $=0.6$, b. oak litter LCI estimated from Magill and Aber (1998) including an alternative model LCI threshold = 0.45; c. maple litter LCI estimated from Magill and Aber (1998) including an alternative model LCI threshold = 0.55 . Enzyme data used in $\mathrm{b}$ and $\mathrm{c}$ are from Carreiro et al. (2000).

\section{Discussion}

Overall, model results were consistent with observed patterns of decline in proportional allocation of cellulolytic versus ligninolytic enzyme activity with increasing LCI in decaying litter despite differences between studies in the threshold value of LCI at which this proportion began to decline. To our knowledge, this represents the first attempt 
Post-print published in revue Soil Biology and Biochemistry, Volume 141, February 2020, 107689

to calculate the allocations of enzymes associated with the degradation of the primary polysaccharide and polyphenol components of plant cell walls, which together account for the largest fraction of dead organic matter in most terrestrial ecosystems. Unfortunately, too few experimental data exist to provide additional insights to the controls on these patterns.

Variations in the apparent LCI threshold among studies may result from differences in lignin and polysaccharide assays, the oxidative enzymes measured, and characteristics of study sites. For example, Snajdr et al. (2011) measured Klason lignin and Magill and Aber (1998) used near infrared reflectance spectroscopy (NIRS) to estimate lignin content. These measuring techniques yield different values that are not necessarily comparable, e.g., Van Soest measurements are usually lower than Klason measurements (Van Soest et al. 2018). Similarly, polysaccharide assay methodology varied across these studies. Snajdr et al. (2011) measured cellulose using gas chromatography after acid hydrolysis, whereas Magill and Aber (1998) used near infrared spectroscopy (NIRS). In addition, the NIRS technique is predictive, with reflectance spectra calibrated using either Van Soest or Klason lignin and cellulose measurements, adding further variation to estimates of LCI (Brinkmann et al. 2002). For both studies, we calculated LCI based on the combined cellulose and hemicellulose content of remaining litter, but differences measuring these polysaccharides add uncertainty to estimates of LCI.

Another source of variability when comparing studies is that differences in oxidative enzyme methods affect assay sensitivity (Bach et al. 2013). Moreover, soil microbes produce oxidative enzymes for many reasons, including ontogeny and defense as well as carbon and nitrogen acquisition (Burns et al. 2013). Thus, oxidative enzyme activity is not a direct proxy for lignin degradation. Lastly, oxidative enzyme activities are measured only in a relatively small proportion of decomposition studies (Chen et al. 2018), providing a limited suite of data for generalization. For all of these reasons, it is remarkable that our simulations showed similarities to these uncertain observations.

Finally, lignin decay is sensitive to a variety of factors. Site and litter type, as well as litter nitrogen content, have significant effects on lignin decomposition (Carreiro et al. 2000, Herman et al. 2008). Two of the decomposition studies used to validate this model (Magill and Aber 1998, Carreiro et al. 2000) took place in the northeastern USA, while the other (Snadjr et al. 2011) took place in the Czech Republic. Site differences are likely a result of variability in soil microbial communities, soil $\mathrm{pH}$, atmospheric nitrogen deposition, and interactions between these controls. At global scales, the effects of nitrogen amendment on oxidative enzyme activity depend on microbial community composition and soil type (Allison et al. 2009, Burns et al. 2013). For example, Frey et al. (2014) found that nitrogen amendment of basidiomycete-dominated temperate and boreal forest soils decreased oxidative enzyme activity, while Iyyemperumal and Shi (2008) found that grassland soils dominated by glomeromycota and ascomycota showed little response. Because the LCI threshold at which oxidative enzymes become active (and lignin decays) is responsive to multiple factors, many more data are needed to elucidate these controls than were available for this study.

In conclusion, our model predicted the proportional allocation of cellulolytic and ligninolytic enzymes during decomposition consistent with the notion that energetic tradeoffs between holocellulose and lignin decay control overall lignocellulose decomposition. This hypothesis is but one of many either proposed or previously observed to drive patterns of lignocellulose decay. Direct observation of specific enzyme activities associated with polysaccharide and 
Post-print published in revue Soil Biology and Biochemistry, Volume 141, February 2020, 107689

polyphenol decay provides a less ambiguous explanation for these patterns than measures of changing litter chemistry and mass loss alone. Moreover, patterns of enzyme allocation with respect to LCI were consistent with a simple, underlying energy balance rationale for lignocellulose decomposition. Thus, this model integrates lignocellulose controls and extracellular enzymatic activities into a single, testable process model. However, our results also indicate that defining more precise relationships between LCI and EEA requires long-term experimental studies that couple measurements of litter chemical quality and specific enzyme assays over sufficient time to observe substantial changes in LCI.

\section{Acknowledgements}

We thank Robert L. Sinsabaugh for providing data used for model validation and feedback that greatly improved the manuscript. We thank Michael N. Weintraub for input during model development. This research was supported by the University of Toledo University Research Funding Opportunities (URFO) Grant and the Environment and Agronomy Division of the National Institute of Agronomic Research (INRA) with the program grant 'scientific challenge' (FungiBioD).

\section{References}

Abramoff, R. Z., Davidson, E. A., Finzi, A. C., 2017. A parsimonious modular approach to building a mechanistic belowground carbon and nitrogen model. Journal of Geophysical Research: Biogeosciences 122, 2418-2434.

Abramoff, R. Z., Xu, X., Hartman, M., O’Brien, S., Feng, W., Davidson, E. A., Finzi, A. C., Moorhead, D. L., Schimel, J., Torn, M., Mayes, M. A., 2018. The Millennial model: in search of measurable pools and transformations for modeling soil carbon in the new century. Biogeochemistry 137, 51-71.
Allison, S. D., 2005. Cheaters, diffusion and nutrients constrain decomposition by microbial enzymes in spatially structured environments. Ecology Letters 8, 626-635.

Allison, S. D., LeBauer, D. S., Ofrecio, M. R., Reyes, R., Ta, A. M., Tran, T. M., 2009. Low levels of nitrogen addition stimulate decomposition by boreal forest fungi. Soil Biology \& Biochemistry 41, 293-302.

Bach, C. E., Warnock, D. D., Van Horn, D. J., Weintraub, M. N., Sinsabaugh, R. L., Allison, S. D., German, D. P., 2013. Measuring phenol oxidase and peroxidase activities with pyrogallol, L-DOPA, and ABTS: effect of assay conditions and soil type. Soil Biology \& Biochemistry 67, 183-191.

Bar-Even, A., Noor, E., Savir, Y., Liebermeister, W., Davidi, D., Tawfik, D. S., Milo, R., 2011. The moderately efficient enzyme: evolutionary and physicochemical trends shaping enzyme parameters. Biochemistry 50, 4402-4410.

Bengtsson, F., Rydin, H., Hájek, T., 2018. Biochemical determinants of litter quality in 15 species of Sphagnum. Plant \& Soil 425, 161-176.

Berg, B., Staaf, H., 1980. Decomposition rate and chemical changes of Scots pine needle litter. II. Influence of chemical composition. Ecological Bulletins, 373-390.

Boerjan, W., Ralph, J., Baucher, M. 2003. Lignin biosynthesis. Annual Review of Plant Biology 54, 519-546.

Brinkmann, K., Blaschke, L., Polle, A., 2002. Comparison of different methods for lignin determination as a basis for calibration of nearinfrared reflectance spectroscopy and implications of lignoproteins. Journal of Chemical Ecology 28, 2483-2501.

Burns, R.G., DeForest, J.L., Marxsen, J., Sinsabaugh, R.L., Stronberger, M.E., Wallenstein, M.D., Weintraub, M.N., Zoppini, A., 2013. Soil enzymes in a changing environment: Current knowledge and future directions. Soil Biology \& Biochemistry 58, 216-234.

Campbell, E. E., Parton, W. J., Soong, J. L., Paustian, K., Hobbs, N. T., Cotrufo, M. F., 2016. Using litter chemistry controls on microbial processes to partition litter carbon fluxes with the litter decomposition and leaching (LIDEL) model. Soil Biology \& Biochemistry 100, 160-174.

Carreiro, M. M., Sinsabaugh, R. L., Repert, D. A., Parkhurst, D. F., 2000. Microbial enzyme shifts explain litter decay responses to simulated nitrogen deposition. Ecology 81, 2359-2365. 
Post-print published in revue Soil Biology and Biochemistry, Volume 141, February 2020, 107689

Chen, J., Luo, Y., García Palacios, P., Cao, J., Dacal, M., Zhou, X., Li, J., Xia, J., Niu, S., Yang, H., Shelton, S., 2018. Differential responses of carbon degrading enzyme activities to warming: Implications for soil respiration. Global Change Biology 24, 4816-4826.

Cotrufo, M. F., Soong, J. L., Horton, A. J., Campbell, E. E., Haddix, M. L., Wall, D. H., Parton, W. J., 2015. Formation of soil organic matter via biochemical and physical pathways of litter mass loss. Nature Geoscience 8, 776.

Frey, S. D., Ollinger, S., Nadelhoffer, K., Bowden, R., Brzostek, E., Burton, A., Caldwell, B. A., Crow, S., Goodale, C. L., Grandy, A. S., Finzi, A., Kramer, M. G., Lajtha, K., LeMoine, J., Martin, M., McDowell, W. H., Minocha, R., Sadowsky, J. J., Templer, P. H., Wickings, K., 2014. Chronic nitrogen additions suppress decomposition and sequester soil carbon in temperate forests. Biogeochemistry 121, 305-316.

Hammel, K. E., 1997. Fungal degradation of lignin. Driven by nature: plant litter quality and decomposition 33-45. Oxfordshire, UK: Centre for Agriculture and Bioscience International.

Herman, J., Moorhead, D. L., Berg, B., 2008. The relationship between rates of lignin and cellulose decay in aboveground forest litter. Soil Biology \& Biochemistry 40, 2620-2626.

Iyyemperumal, K., Shi, W., 2008. Soil enzyme activities in two forage systems following application of different rates of swine lagoon effluent or ammonium nitrate. Applied Soil Ecology 38, 128136.

Kari, J., Olsen, J. P., Jensen, K., Badina, S. F., Krogh, K. B. R. M., Borch, K., Westh, P., 2019. Sabatier principle for interfacial (heterogeneous) enzyme catalysis. ACS Catalysis 8, 11966-11972.

Kirk, T. K., Farrell, R. L., 1987. Enzymatic "combustion": the microbial degradation of lignin. Annual Reviews in Microbiology 41, 465501.

Klemm, D., Heublein, B., Fink, H. P., Bohn, A., 2005. Cellulose: fascinating biopolymer and sustainable raw material. Angewandte Chemie International Edition 44, 3358-3393.

Klipp, E., Heinrich, R., 1994. Evolutionary optimization of enzyme kinetic parameters; effect of constraints. Journal of Theoretical Biology 17, 309-323.

Lashermes, G., Gainvors-Claisse, A., Recous, S., Bertrand, I., 2016. Enzymatic strategies and carbon use efficiency of a litter-decomposing fungus grown on maize leaves, stems, and roots. Frontiers in Microbiology 7, 1315.
Magill, A. H., Aber, J. D., 1998. Long-term effects of experimental nitrogen additions on foliar litter decay and humus formation in forest ecosystems. Plant \& Soil 203, 301-311.

Meentemeyer, V., 1978. Macroclimate and lignin control of litter decomposition rates. Ecology 59, 465-472.

Melillo, J. M., Aber, J. D., Linkins, A. E., Ricca, A., Fry, B., Nadelhoffer, K. J., 1989. Carbon and nitrogen dynamics along the decay continuum: plant litter to soil organic matter. Plant \& Soil 115, 189-198.

Moorhead, D. L., Lashermes, G., Sinsabaugh, R. L., 2012. A theoretical model of $\mathrm{C}$-and $\mathrm{N}$-acquiring exoenzyme activities, which balances microbial demands during decomposition. Soil Biology \& Biochemistry 53, 133-141.

Moorhead, D. L., Lashermes, G., Sinsabaugh, R. L., Weintraub, M. N., 2013. Calculating co-metabolic costs of lignin decay and their impacts on carbon use efficiency. Soil Biology \& Biochemistry 66, 17-19.

Paul, E., 1981. Mineralization and immobilization of soil nitrogen by microorganisms. Ecologicla Bulletin (Stockholm) 33, 179-195.

Schimel, J. P., Weintraub, M. N., 2003. The implications of exoenzyme activity on microbial carbon and nitrogen limitation in soil: a theoretical model. Soil Biology \& Biochemistry 35, 549-563.

Šnajdr, J., Cajthaml, T., Valášková, V., Merhautová, V., Petránková, M., Spetz, P., Leppänen, K., Baldrian, P., 2011. Transformation of Quercus petraea litter: successive changes in litter chemistry are reflected in differential enzyme activity and changes in the microbial community composition. FEMS Microbiology Ecology 75, 291-303.

Sinsabaugh, R. L., Belnap, J., Findlay, S. G., Shah, J. J. F., Hill, B. H., Kuehn, K. A., Kuske, C. R., Litvak, M. E., Martinez, N. G., Moorhead, D. L., Warnock, D. D., 2014. Extracellular enzyme kinetics scale with resource availability. Biogeochemistry 121, 287-304.

Sinsabaugh, R. L. (2010). Phenol oxidase, peroxidase and organic matter dynamics of soil. Soil Biology \& Biochemistry 42, 391-404.

Sinsabaugh, R. L., Shah, J. J. F., 2011. Ecoenzymatic stoichiometry of recalcitrant organic matter decomposition: the growth rate hypothesis in reverse. Biogeochemistry 102, 31-43.

Soong, J. L., Parton, W. J., Calderon, F., Campbell, E. E., Cotrufo, M. F., 2015. A new conceptual model on the fate and controls of fresh and pyrolized plant litter decomposition. Biogeochemistry 124, 27-44. 
Post-print published in revue Soil Biology and Biochemistry, Volume 141, February 2020, 107689

Talbot, J. M., Treseder, K. K., 2012. Interactions among lignin, cellulose, and nitrogen drive litter chemistry-decay relationships. Ecology 93, 345354.

Tang, J. Y., 2015. On the relationships between the Michaelis-Menten kinetics, reverse MichaelisMenten kinetics, equilibrium chemistry approximation kinetics, and quadratic kinetics, Geoscientific Model Development 8, 3823-3835.

Van Soest, P. J., Robertson, J. B., Barry, M. C., 2018. Soluble lignin and its relation to klason lignin, acid-detergent lignin, and digestibility of NDF. Ithaca, NY: Cornell University.

Whittinghill, K. A., Currie, W. S., Zak, D. R., Burton, A. J., Pregitzer, K. S., 2012. Anthropogenic N deposition increases soil $\mathrm{C}$ storage by decreasing the extent of litter decay: analysis of field observations with an ecosystem model. Ecosystems 15, 450-461.

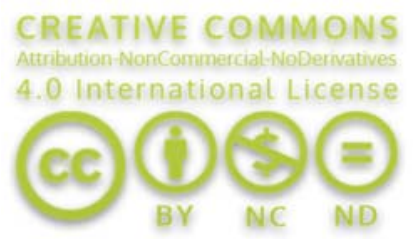

